\title{
Electrolyte Additives for Phosphoric Acid Fuel Cells
}

\author{
Gang, Xiao; Hjuler, H.A.; Olsen, C.A.; Berg, Rolf W.; Bjerrum, Niels
}

Published in:

Journal of The Electrochemical Society

Link to article, DOI:

$10.1149 / 1.2056224$

Publication date:

1993

Document Version

Publisher's PDF, also known as Version of record

Link back to DTU Orbit

Citation (APA):

Gang, X., Hjuler, H. A., Olsen, C. A., Berg, R. W., \& Bjerrum, N. (1993). Electrolyte Additives for Phosphoric Acid Fuel Cells. Journal of The Electrochemical Society, 140(4), 896-902. https://doi.org/10.1149/1.2056224

\section{General rights}

Copyright and moral rights for the publications made accessible in the public portal are retained by the authors and/or other copyright owners and it is a condition of accessing publications that users recognise and abide by the legal requirements associated with these rights.

- Users may download and print one copy of any publication from the public portal for the purpose of private study or research.

- You may not further distribute the material or use it for any profit-making activity or commercial gain

- You may freely distribute the URL identifying the publication in the public portal

If you believe that this document breaches copyright please contact us providing details, and we will remove access to the work immediately and investigate your claim. 


\title{
Electrolyte Additives for Phosphoric Acid Fuel Cells
}

\author{
Xioo Gang \\ Materials Science Group, Chemistry Department A, The Technical University of Denmark, \\ DK-2800 Lyngby, Denmark \\ H. A. Hjuler* \\ NKT Research Center, DK-2605 Brфndby, Denmark \\ C. Olsen, R. W. Berg, and N. J. Bjerrum* \\ Materials Science Group, Chemistry Department A, The Technical University of Denmark, \\ DK-2800 Lyngby, Denmark
}

\begin{abstract}
Electrochemical characteristics of a series of modified phosphoric acid electrolytes containing fluorinated carbon compounds and silicone fluids as additives are presented. When used in phosphoric acid fuel cells, the modified electrolytes improve the performance due to the enhanced oxygen reduction rate. Among useful additives we found potassium perfluorohexanesulfonate $\left(\mathrm{C}_{6} \mathrm{~F}_{13} \mathrm{SO}_{3} \mathrm{~K}\right)$, potassium nonafluorobutanesulfonate $\left(\mathrm{C}_{4} \mathrm{~F}_{9} \mathrm{SO}_{3} \mathrm{~K}\right)$, perfluorotributylamine $\left[\left(\mathrm{C}_{4} \mathrm{~F}_{9}\right)_{3} \mathrm{~N}\right]$, and polymethylsiloxanes $\left[\left(-\mathrm{Si}\left(\mathrm{CH}_{3}\right)_{2} \mathrm{O}-{ }_{-}\right) n\right.$. The wettability of the electrodes by the modified electrolytes also is discussed, as is fuel-cell performance with the modified electrolytes. Specific conductivity measurements of some of the modified phosphoric acid electrolytes are reported. At a given temperature, the conductivity of the $\mathrm{C}_{4} \mathrm{~F}_{9} \mathrm{SO}_{3} \mathrm{~K}$-modified electrolyte decreases with an increasing amount of the additive; the conductivity of the $\left(\mathrm{C}_{4} \mathrm{~F}_{9}\right)_{3} \mathrm{~N}$-modified electrolyte, remains at the same value as the conductivity of the pure phosphoric acid. At a given composition, the conductivity of any modified electrolyte increases with temperature. We conclude that the improved cell performance for modified electrolytes is not due to any increase in conductivity.
\end{abstract}

It is well established that the oxygen reduction rate in various perfiuorinated acids, such as $\mathrm{CF}_{3} \mathrm{SO}_{3} \mathrm{H}$, is substantially higher than in phosphoric acid because of their higher $\mathrm{O}_{2}$ solubilities and diffusion coefficients, as well as weaker adsorption of their anion to the platinum catalysts. ${ }^{1-9}$ However, the use of, e.g., $\mathrm{CF}_{3} \mathrm{SO}_{3} \mathrm{H}$ in a practical fuel cell is limited due to its high vapor pressure and lower conductivity at relatively high concentrations as well as its pronounced ability to wet Teflon ${ }^{\circledR}$-bonded Pt electrodes. Therefore, similar acids with higher molecular mass (lower vapor pressure) have been considered. Electrolytes with longer fluorocarbon "tail(s)", however, have lower contact angles with Teflon and tend to wet Teflon-bonded gas-diffusion electrodes (filling the pores). ${ }^{10}$ Therefore, such electrolytes also are not suitable for fuel cells based on such electrodes. However, due to their desirable properties they might be considered as additives to the phosphoric acid. ${ }^{10}$

A new idea is to use salts of perfluorinated acids as additives. ${ }^{11}$ These salts are powders which are easy to store, uncorrosive under normal circumstances, and in $\mathrm{H}_{3} \mathrm{PO}_{4}$ they should dissociate and function as their corresponding acids. Potassium perfluorohexanesulfonate (hereafter referred to as $\mathrm{C}_{6}$-salt, $\mathrm{C}_{6} \mathrm{~F}_{13} \mathrm{SO}_{3} \mathrm{~K}$ ), and potassium nonafluorobutanesulfonate (hereafter referred to as $\mathrm{C}_{4}$-salt, $\mathrm{C}_{4} \mathrm{~F}_{9} \mathrm{SO}_{3} \mathrm{~K}$ ), were chosen for this investigation.

In 1966 Clark and Gollan ${ }^{12}$ dramatically demonstrated the oxygen-carrying capability of perfluorochemicals by immersing living mice completely in a fluorocarbon liquid and noting their prolonged survival. Since then, stable inert aqueous emulsions of perfluorochemicals that can act as oxygen-transport fluids during complete blood transfusion in animals have been prepared. ${ }^{13}$ The oxygen solubility of some perfluorochemicals is very high, due to the very low intermolecular attraction between the perfluorochemical molecules. When equilibrated with $100 \%$ oxygen at $25^{\circ} \mathrm{C}$, the oxygen content of e.g., perfluorotributylamine emulsion is $0.39 \mathrm{~cm}^{3} / \mathrm{cm}^{3} .{ }^{14}$ For the above mentioned reasons, perfluorotributylamine (hereafter referred to as $\mathrm{C}_{4}$-amine, $\left.\left(\mathrm{C}_{4} \mathrm{~F}_{9}\right)_{3} \mathrm{~N}\right)$, was chosen as one of the additives to the $\mathrm{H}_{3} \mathrm{PO}_{4}$ electrolyte.

In the same paper, Clark and Gollan ${ }^{12}$ also reported that mice, rats, and goldfish can survive complete immersion in

* Electrochemical Society Active Member. oxygen-saturated silicone oils (polymethylsiloxanes) for prolonged periods because oxygen is very soluble in certain silicone oils. A given volume of oxygen-saturated silicone oil contains $50 \%$ more oxygen as the same volume of air or whole blood. Therefore we expected that silicone fluids, as additives to $\mathrm{H}_{3} \mathrm{PO}_{4}$, can improve oxygen reduction kinetics, and hence silicone oil DC-550 and silicone oil DC-200 were included as examples in this investigation.

The study of oxygen reduction in perfluoroalkane sulfonic acids, particularly in the model compound, trifluoromethane sulfonic acid $\left(\mathrm{CF}_{3} \mathrm{SO}_{3} \mathrm{H}\right.$, TFMSA), has been of much interest $t^{4,5,7,15-17}$ from the standpoint of identifying alternative acid electrolytes instead of concentrated phosphoric acid for fuel-cell applications. The possibility of adding electrolyte components to the concentrated $\mathrm{H}_{3} \mathrm{PO}_{4}$, however, is another concept which deserves investigation. A rotating disk electrode study ${ }^{18}$ of the $\mathrm{O}_{2}$ reduction on platinum has been carried out in mixtures of concentrated $\mathrm{H}_{3} \mathrm{PO}_{4}$ and $\mathrm{CF}_{3} \mathrm{SO}_{3} \mathrm{H}$ at room temperature. The diffusion-limited current increased with increasing amounts of $\mathrm{CF}_{3} \mathrm{SO}_{3} \mathrm{H}$ added to the $\mathrm{H}_{3} \mathrm{PO}_{4}$ and the $\mathrm{O}_{2}$ reduction rates are faster in the mixed acids than in $\mathrm{H}_{3} \mathrm{PO}_{4}$ alone.

In view of these considerations, we report the following experiments to develop fuel cells based on phosphoric acid electrolytes containing fluorinated carbon compounds or silicone fluids.

\section{Experimental}

Modified electrolytes.-The following methods of preparing modified electrolytes are applied for electrochemical measurement, conductivity measurement, and for practical fuel-cell testing. Phosphoric acid $(85 \%$, analytical grade, Riedel-de Haën) was purified by treatment with hydrogen peroxide and concentrated to $100 \%$ by heating. The resulting phosphoric acid concentration determination was checked both by titration and by density comparison (concentration about $100 \pm 1 \%$ ).

The following chemicals were used as additives: potassium perfluorohexanesulfonate, $\mathrm{C}_{6} \mathrm{~F}_{13} \mathrm{SO}_{3} \mathrm{~K}$ (a white powder of $98 \%$ purity from Riedel-de Haën), potassium nonafluorobutanesulfonate, $\mathrm{C}_{4} \mathrm{~F}_{9} \mathrm{SO}_{3} \mathrm{~K}$ (a white powder of $98 \%$ purity (from Aldrich Chemical Company, Inc.)), perfluorotributylamine, $\left(\mathrm{C}_{4} \mathrm{~F}_{9}\right)_{3} \mathrm{~N}$ (a transparent liquid of technical grade ca. $90 \%$ purity (from PCR Incorporated)), 
and silicone oils DC-550 (Si-550) and DC-200 (Si-200) (transparent liquids from Dow Corning).

All additives were added in small amounts $[0.5$ to 3 weight percent (w/o)] to the $100 \%$ phosphoric acid and each batch was agitated with a magnetic stirrer at $100^{\circ} \mathrm{C}$. An emulsion was achieved which was used immdiately.

Electrochemical experiments.-For the electrochemical measurements (voltammetry and chronoamperometry), a small Pt working electrode was made in this way: a Pt wire of radius $250 \mu \mathrm{m}$ (99.99\%, purchased from Dansk Hollandsk Adelmetal) was sealed in a glass capillary (Pyrex). The wire was cut at the end of the glass and plane polished with $0.25 \mu \mathrm{m}$ diamond paste (at a $90^{\circ}$ angle to the center of the rod).

The electrochemical cell contained three electrodes: the Pt working electrode, a dynamic hydrogen electrode (DHE, platinized Pt) used as reference electrode, and a Pt counterelectrode. The electrochemical experiment was designed so that a $1 \mathrm{~mA} / \mathrm{cm}^{2}$ constant cathodic current was passing the dynamic hydrogen electrode from the counterelectrode. The evolved hydrogen creates a hydrogen electrode whose potential, due to a small overvoltage, is $20-40 \mathrm{mV}$ more negative than the potential of the reversible hydrogen electrode. $^{19}$ The electrochemical cell has a jacket filled with silicone oil kept at constant temperature.

Purified oxygen $(\geq 99.998 \%, A G A$ A/S $)$ and purified nitrogen $(\geq 99.998 \%$, Hede Nielsen A/S) were pretreated by passage through an electrolyte solution of the same concentration as that used in the electrochemical cell and bubbled into the cell through a glass capillary.

Saturation of the electrolytes (with $\mathrm{O}_{2}$ or $\mathrm{N}_{2}$ ) was achieved by bubbling the gas through it for at least $2 \mathrm{~h}$ prior to the measurements.

An electrochemical instrument built in this laboratory was used throughout the work, both for taking cyclic voltammograms and for the chronoamperometric current transient measurements. Current vs, potential and time were recorded on an $\mathrm{X}-\mathrm{Y}$ recorder (Hewlett Packard 7004B).

Conductivity measurements.-Measurements on the modified electrolytes were made with a conductivity meter (Radiometer CDM 83, Copenhagen) using conductivity cells. The cell constants were determined using a standard 0.1 Demal $\mathrm{KCl}$ solution. ${ }^{20}$ The conductivity cell has been described previously. ${ }^{21}$ Measurements were done in an oil bath with a temperature control within $\pm 0.5^{\circ} \mathrm{C}$.

Fuel-cell measurements.-The fuel-cell housing used to test the electrolytes was a product from Giner, Inc. (General License GLV). Heat was provided to the cell by two flexible electrical heaters glued onto each steel end plate. The temperature in the cell remained within $\pm 1^{\circ} \mathrm{C}$.

\section{Results and Discussion}

Voltammetry.-The preliminary testing of purity level, adsorption characteristics and oxygen reduction behavior on $\mathrm{Pt}$ were carried out using cyclic voltammetry at a sweep rate of $100 \mathrm{mV} / \mathrm{s}$. Reference voltammograms of $\mathrm{Pt}$ in $100 \mathrm{w} / \mathrm{o} \mathrm{H}_{3} \mathrm{PO}_{4}$ were recorded to allow for comparison of $\mathrm{Pt}$ behaviors in the modified electrolytes. Cyclic voltammograms of the $\mathrm{Pt}$ working electrode in electrolytes saturated with nitrogen at $100^{\circ} \mathrm{C}$ are shown in Fig. 1 and 2 . For comparison, these voltammograms of modified electrolytes are superimposed on a voltammogram of the same electrode in $100 \mathrm{w} / \mathrm{o} \mathrm{H}_{3} \mathrm{PO}_{4}$. The cycles shown are the ones obtained after several scans (i.e., after the cycles started to repeat themselves).

The voltamograms in $100 \mathrm{w} / \mathrm{o}_{3} \mathrm{PO}_{4}$ show well-characterized hydrogen adsorption-desorption peaks and the oxide formation and reduction regions are well defined. The general shape of the voltammograms suggests that this electrolyte is reasonably clean. The voltammograms with the modified electrolytes show all the features expected from such concentrated acid mixtures, except that the hydrogen adsorption-desorption peaks are relatively poorly resolved. This indicates that these electrolytes contain

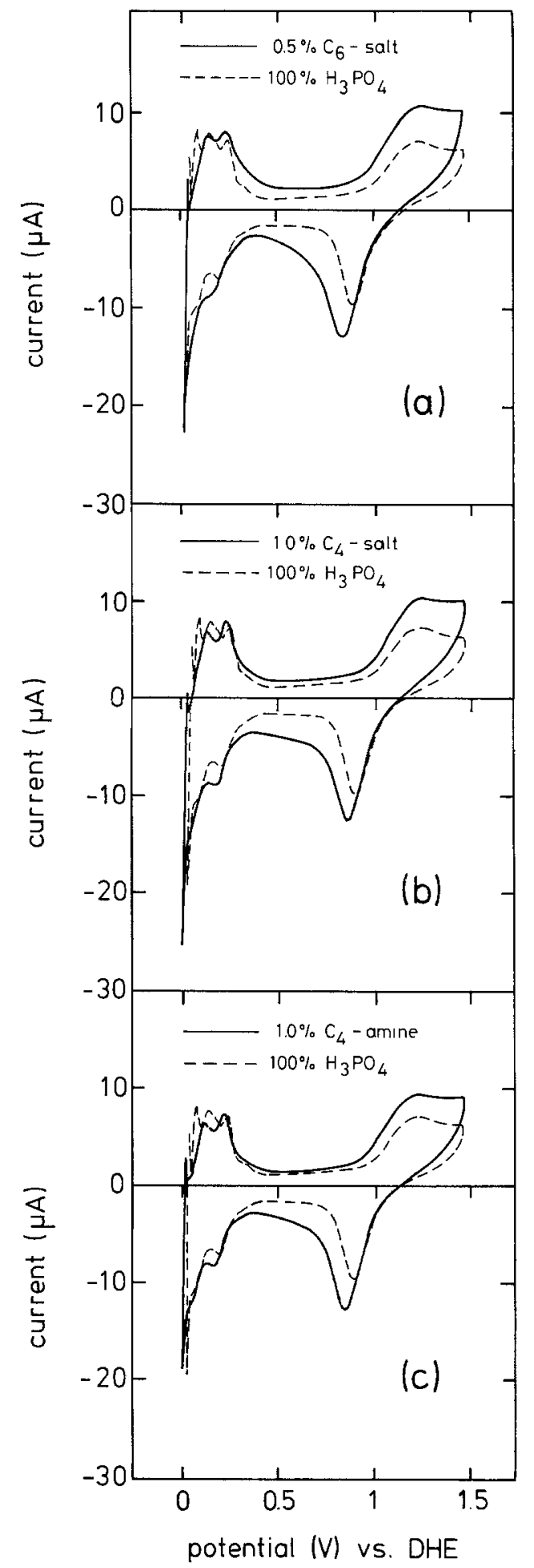

Fig. 1. Cyclic voltammograms of the Pt working electrode in $\mathrm{N}_{2}$-saturated electrolytes: $100 \mathrm{w} / 0 \mathrm{H}_{3} \mathrm{PO}_{4}$ or modified electrolytes contain-

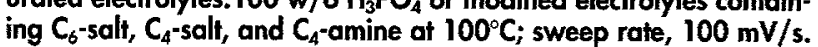

small amounts of impurities which most likely are the additives themselves. Figure $2 \mathrm{a}$ and $\mathrm{b}$ with the modified electrolytes exhibit a peak before the onset of the oxide formation. The origin of this peak is unknown but since it is found in two different types of silicone oils it probably is due to an oxidation of the silicone oil and not due to an impurity.

The modified electrolytes are expected to exhibit weaker adsorption to the $\mathrm{Pt}$ surface than $100 \% \mathrm{H}_{3} \mathrm{PO}_{4}$. Therefore it is expected that the onsets of the anodic oxide film formations in the modified electrolytes are less anodic than in $100 \% \mathrm{H}_{3} \mathrm{PO}_{4}$. These expected effects can be seen in Fig. 1 and 2 (the onsets of the anodic oxide film formations in the 


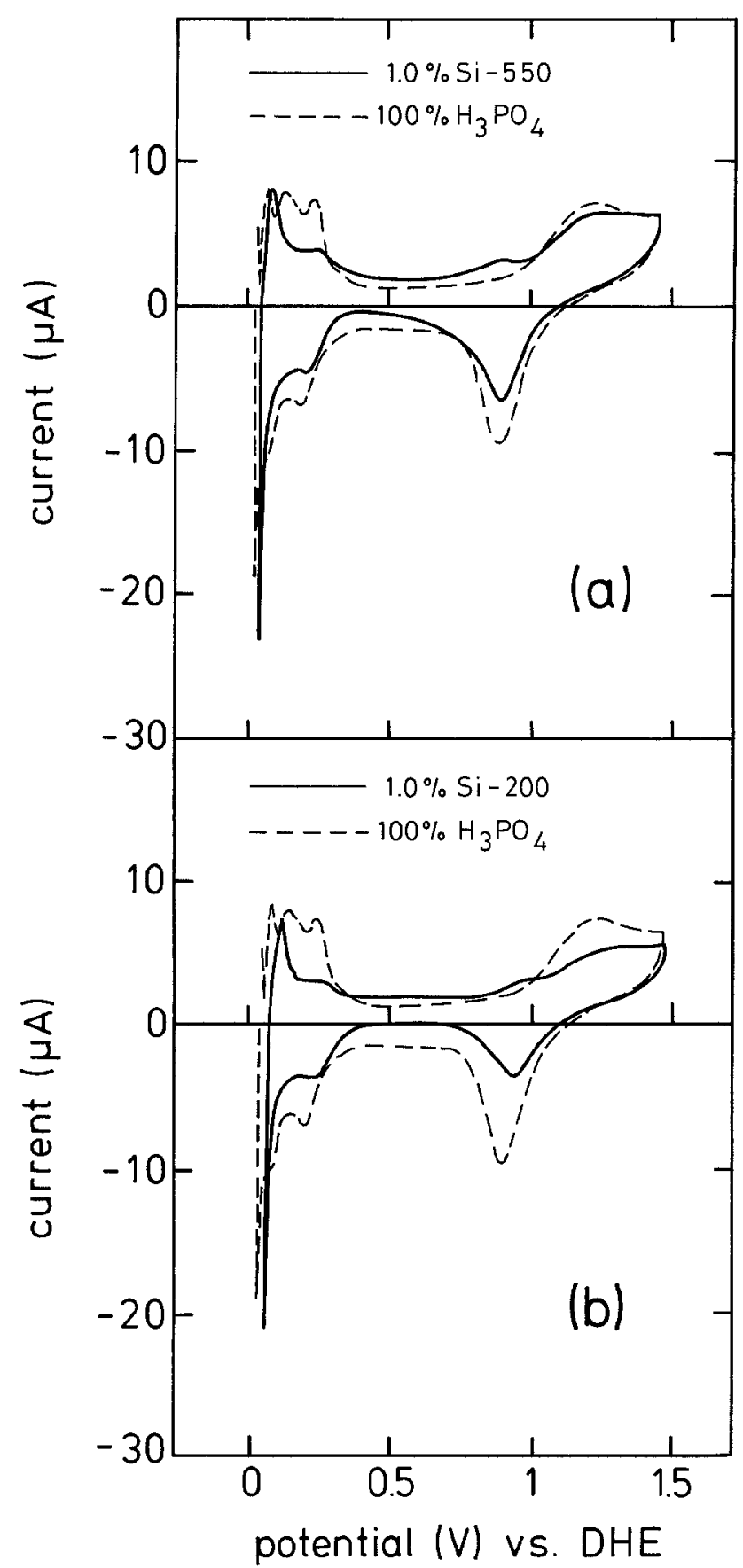

Fig. 2. Cyclic voltammograms of the $\mathrm{Pt}$ working electrode in $\mathrm{N}_{2}$-saturated electrolytes: $100 \mathrm{w} / 0 \mathrm{H}_{3} \mathrm{PO}_{4}$ or modified electrolytes containing $\mathrm{Si}-550, \mathrm{Si}-200$ at $100^{\circ} \mathrm{C}$; sweep rate, $100 \mathrm{mV} / \mathrm{s}$.

modified electrolytes are about $0.8 \mathrm{~V}$ in most cases compared to about $1.0 \mathrm{~V}$ in the $100 \% \mathrm{H}_{3} \mathrm{PO}_{4}$ electrolyte).

For each of the electrolytes, the heights of the oxide formation and oxide reduction peaks increase with increasing temperature. As an example, the voltammograms of the $0.5 \mathrm{w} / \mathrm{o} \mathrm{C}_{6} \mathrm{~F}_{13} \mathrm{SO}_{3} \mathrm{~K}$-modified electrolyte at different temperatures are shown in Fig. 3, to illustrate the above-mentioned effect.

Oxygen solubility and diffusivity.-Measurements of the solubility and the diffusion coefficient of $\mathrm{O}_{2}$ in $100 \% \mathrm{H}_{3} \mathrm{PO}_{4}$ and in the modified electrolytes were carried out using the working electrode in a temperature range of 75 to $150^{\circ} \mathrm{C}$. The $\mathrm{O}_{2}$ reduction is entirely under diffusion control when the electrode potential is below $0.30 \mathrm{~V} v s$. reversible hydrogen electrode (RHE) ${ }^{22}$ Therefore, since the potential difference between a reversible hydrogen electrode and dynamic hydrogen electrode is only $20-40 \mathrm{mV}^{19}$ we recorded the chronoamperometric current transients on the electrode in

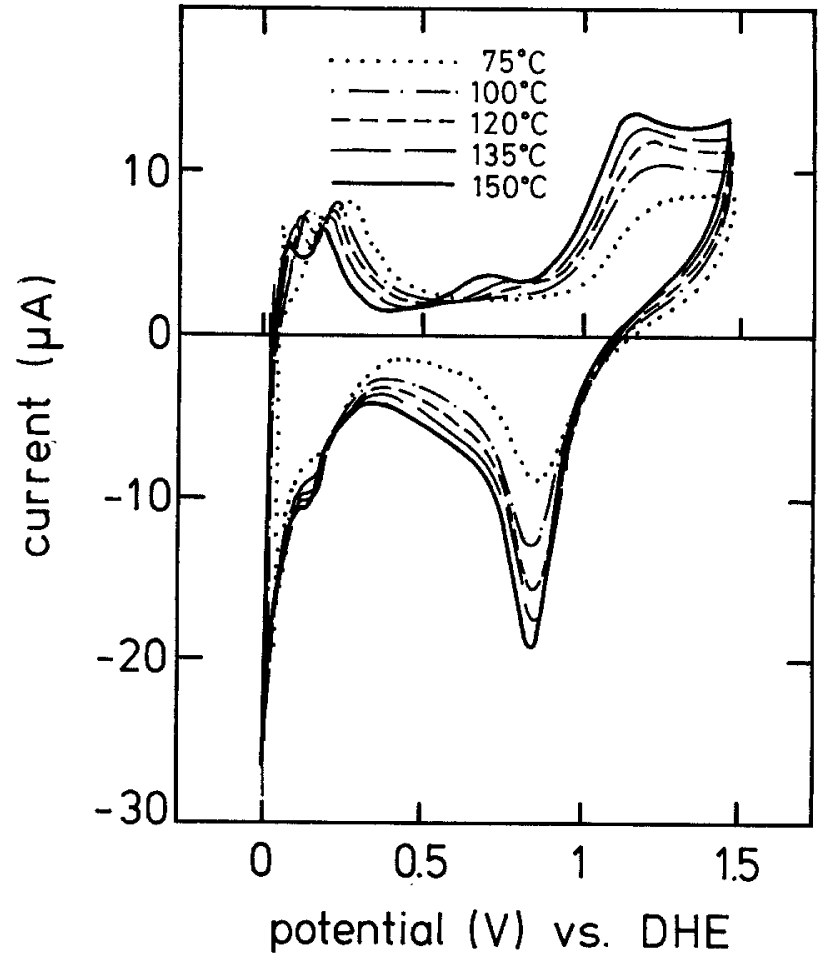

Fig. 3. Cyclic voltammograms of the Pt working electrode in $\mathrm{N}_{2}$-saturated electrolyte containing $0.5 \mathrm{w} / 0 \mathrm{C}_{6}$-salt at different temperatures; sweep rate, $100 \mathrm{mV} / \mathrm{s}$.

$\mathrm{O}_{2}$-saturated electrolytes, at $0.30 \mathrm{~V} v s$. the dynamic hydrogen electrode, under which conditions presumably the $\mathrm{O}_{2}$ reduction is entirely under diffusion control. The $I$ vs. $t^{-1 / 2}$ plots constructed from the recorded current transient data (for $\mathrm{O}_{2}$ reduction on the $\mathrm{Pt}$ working electrode in $100 \%$ $\mathrm{H}_{3} \mathrm{PO}_{4}$ and in the modified electrolytes at various temperatures) are shown in Fig. 4 and 5. Prior to recording the $i$ - $t$ transients, the electrode was pretreated by stepping the potential between 1.4 and $0.3 \mathrm{~V}$ three times.

The solubility, $C_{\mathrm{O}_{2}}$, and diffusion coefficient, $D_{\mathrm{O}_{2}}$, of $\mathrm{O}_{2}$ were calculated from the slopes $(B)$ and intercepts $(A)$ of these plots using established mathematical expressions ${ }^{23}$

$$
\begin{aligned}
& D_{\mathrm{O}_{2}}=\alpha^{2} A^{2} / \pi B^{2} \\
& C_{\mathrm{O}_{2}}=B^{2} / n F A \alpha^{3}
\end{aligned}
$$

where $\alpha$ is the radius of the working electrode, $F$ is the Faraday constant, and $n$ the number of electrons involved in the electrode reaction ( $n=4$ for $\mathrm{O}_{2}$ reduction to water). The values of $\mathrm{C}_{\mathrm{O}_{2}}$ and $\mathrm{D}_{\mathrm{O}_{2}}$ (and their products) obtained for the modified electrolytes are given in Table I, along with corresponding values for $100 \% \mathrm{H}_{3} \mathrm{PO}_{4}$.

The results of Table I demonstrate that both the solubility and the diffusion coefficient of $\mathrm{O}_{2}$ in the modified electrolytes are higher than the corresponding values in $100 \%$ $\mathrm{H}_{3} \mathrm{PO}_{4}$ (except for some irregular values which might be due to inaccuracy of some measurements). The product $\mathrm{D}_{\mathrm{O}_{2}} \mathrm{C}_{\mathrm{O}_{2}}$ accounts for both solubility and diffusivity of $\mathrm{O}_{2}$ molecules. The improvements in the $\mathrm{D}_{\mathrm{O}_{2}} \mathrm{C}_{\mathrm{O}_{2}}$ products of the modified electrolytes comparing with those of the $100 \%$ $\mathrm{H}_{3} \mathrm{PO}_{4}$ are obvious. It indicates that the modified electrolytes can improve the oxygen reduction rate.

As mentioned, phosphoric acid has some undesirable properties, such as a low oxygen solubility, low oxygen diffusivity, and high anion adsorption on the platinum catalyst. With the modified electrolytes studied here, these problems are generally overcome. It has been reported that the adsorption of $\mathrm{CF}_{3} \mathrm{SO}_{3}^{-}$ions onto a $\mathrm{Pt}$ surface is weak. ${ }^{24}$ Apparently the $\mathrm{C}_{6} \mathrm{~F}_{13} \mathrm{SO}_{3}^{-}$and $\mathrm{C}_{4} \mathrm{~F}_{9} \mathrm{SO}_{3}^{-}$ions behave similarly. These negative ions of the corresponding fluorinated acids with better $\mathrm{O}_{2}$ solubilities and diffusivities, result in improved cell performance when used as fuel-cell electrolytes. 

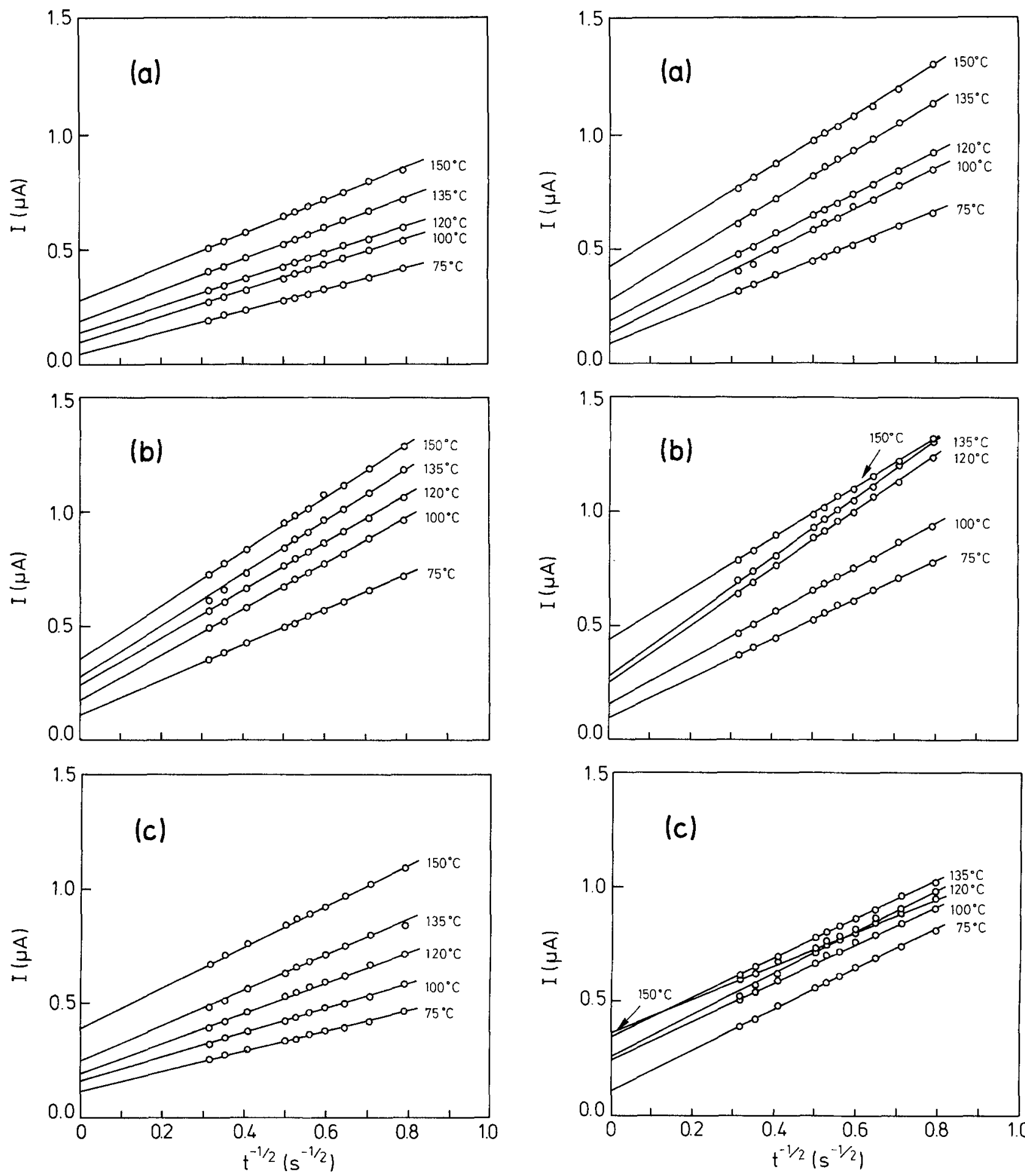

Fig. 4. Plots of I v5. $f^{-1 / 2}$ for $\mathrm{O}_{2}$ reduction on $\mathrm{Pt}$ in $100 \% \mathrm{H}_{3} \mathrm{PO}_{4}(\mathrm{a})$ $0.5 \mathrm{w} / 0 \mathrm{C}_{6}$-salt-modified electrolyte; (b) $1.0 \mathrm{w} / 0 \mathrm{C}_{4}$-salt-modified electrolyte; $(\mathrm{c})$ at different temperatures at a potential of $0.3 \mathrm{~V} v \mathrm{v}$. DHE.

In the $\left(\mathrm{C}_{4} \mathrm{~F}_{9}\right)_{3} \mathrm{~N}$-modified electrolyte, an emulsion is formed. The formation of a separate phase (the emulsion) is evidence of low compatibility between perfluorotributylamine and $\mathrm{H}_{3} \mathrm{PO}_{4}$. At high concentration, phosphoric acid has a strong hydrogen-bonded network structure which apparently separates out the perfluorotributylamine, which forms a second phase (a self-assembling layer). At the electrode/electrolyte interface, the perfluorotributylamine probably forms a physically adsorbed layer (on the electrode surface) with the fluorocarbon tails covering the Pt metal catalyst and the polar amine end pointing toward the bulk phosphoric acid (due to the dipole-dipole interaction).

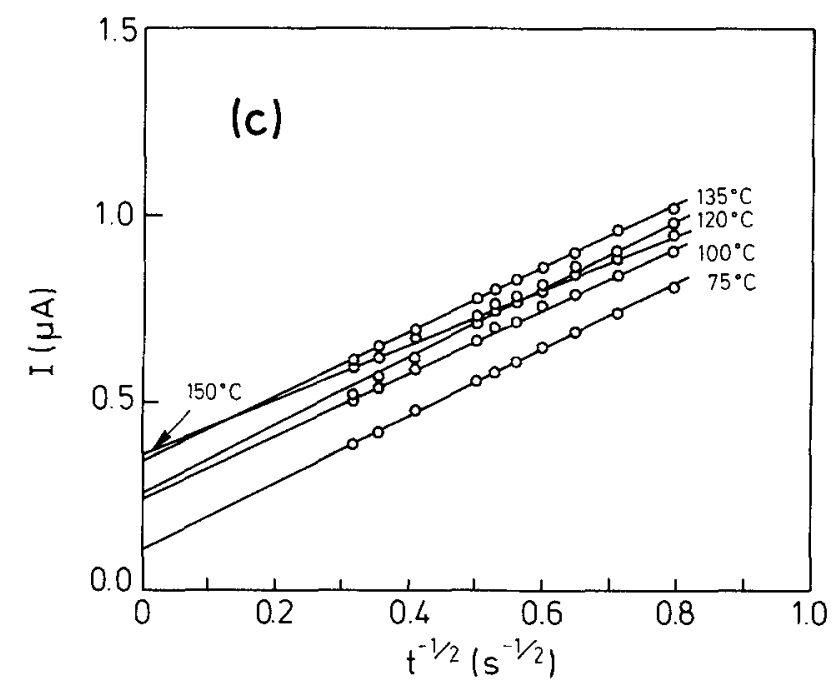

Fig. 5. Plots of I vs. $f^{-1 / 2}$ for $\mathrm{O}_{2}$ reduction on $\mathrm{Pt}$ in $1.0 \mathrm{~W} / \mathrm{o} \mathrm{C}_{4}$-amine (a) $1.0 \mathrm{w} / 0$ Si-550; (b) $1.0 \mathrm{w} / 0$ Si-200; (c) modified electrolyte at different temperatures at a potential of $0.3 \mathrm{~V}$ vs. DHE.

The perfluorotributylamine layer at the electrode/electrolyte interface reduces the activity of phosphoric acid at the electrode surface. This layer may behave like an oasis in which the concentration of oxygen is higher than in bulk phosphoric acid and in which the phosphoric acid has a lower concentration. This oasis environment adjacent to the electrode surface increases the rate of the oxygen reduction. A similar mechanism has been suggested by Razaq et al. for perfluorosulfonimide in phosphoric acid. ${ }^{25}$

The improved oxygen reduction rate in the electrolytes modified with silicone fluids can be explained in the same way because silicone fluids are also oily substances and the modified mixtures are emulsions much like the $\left(\mathrm{C}_{4} \mathrm{~F}_{9}\right)_{3} \mathrm{~N}$ modified mixtures. Therefore they also can form a physi- 
Table I. The solubility and diffusion coefficients of $\mathrm{O}_{2}$ and their product in $100 \% \mathrm{H}_{3} \mathrm{PO}_{4}$ and modified electrolytes at various temperatures.

\begin{tabular}{|c|c|c|c|c|c|c|}
\hline$T\left({ }^{\circ} \mathrm{C}\right)$ & $\begin{array}{c}\mathrm{H}_{3} \mathrm{PO}_{4} \\
(100 \%)\end{array}$ & $\begin{array}{c}\mathrm{C}_{4} \text {-amine } \\
(1.0 \%)\end{array}$ & $\begin{array}{l}\mathrm{C}_{6}-\mathrm{salt} \\
(0.5 \%)\end{array}$ & $\begin{array}{l}\mathrm{C}_{4} \text {-salt } \\
(1.0 \%)\end{array}$ & $\begin{array}{l}\mathrm{Si}-200 \\
(1.0 \%)\end{array}$ & $\begin{array}{l}\mathrm{Si}-550 \\
(1.0 \%)\end{array}$ \\
\hline \multicolumn{7}{|c|}{ Solubility $\mathrm{C}_{\mathrm{O}_{2}} \cdot 10^{7}\left(\mathrm{~mol} / \mathrm{cm}^{3}\right)$} \\
\hline $\begin{array}{r}75 \\
100 \\
120 \\
135 \\
150\end{array}$ & $\begin{array}{l}8.34 \\
5.58 \\
3.94 \\
3.89 \\
3.28\end{array}$ & $\begin{array}{r}9.46 \\
10.53 \\
7.58 \\
7.35 \\
4.75\end{array}$ & $\begin{array}{l}8.65 \\
9.59 \\
7.93 \\
7.16 \\
6.47\end{array}$ & $\begin{array}{l}2.81 \\
2.96 \\
4.23 \\
4.24 \\
3.22\end{array}$ & $\begin{array}{r}11.72 \\
4.84 \\
4.79 \\
3.69 \\
2.56\end{array}$ & $\begin{array}{r}12.20 \\
10.90 \\
10.80 \\
7.66 \\
4.76\end{array}$ \\
\hline \multicolumn{7}{|c|}{ Diffusion coefficient $D_{\mathrm{O}_{2}} \cdot 10^{6}\left(\mathrm{~cm}^{2} / \mathrm{s}\right)$} \\
\hline $\begin{array}{r}75 \\
100 \\
120 \\
135 \\
150\end{array}$ & $\begin{array}{r}1.68 \\
5.51 \\
11.50 \\
16.00 \\
27.20\end{array}$ & $\begin{array}{r}3.07 \\
4.27 \\
8.13 \\
12.20 \\
29.10\end{array}$ & $\begin{array}{r}4.21 \\
5.91 \\
9.61 \\
12.67 \\
18.10\end{array}$ & $\begin{array}{l}13.30 \\
17.70 \\
14.20 \\
18.60 \\
40.90\end{array}$ & $\begin{array}{r}3.16 \\
16.70 \\
18.60 \\
30.40 \\
46.40\end{array}$ & $\begin{array}{r}2.67 \\
4.55 \\
7.36 \\
13.34 \\
29.75\end{array}$ \\
\hline \multicolumn{7}{|c|}{ Product of $C_{\mathrm{O}_{2}}$ and $D_{\mathrm{O}_{2}} C_{\mathrm{O}_{2}} \cdot D_{\mathrm{O}_{2}} 10^{12}(\mathrm{~mol} / \mathrm{cm} \cdot \mathrm{s})$} \\
\hline $\begin{array}{r}75 \\
100 \\
120 \\
135 \\
150\end{array}$ & $\begin{array}{l}1.40 \\
3.07 \\
4.53 \\
6.22 \\
8.92\end{array}$ & $\begin{array}{r}2.90 \\
4.50 \\
6.16 \\
8.97 \\
13.82\end{array}$ & $\begin{array}{r}3.64 \\
5.67 \\
7.62 \\
9.07 \\
11.71\end{array}$ & $\begin{array}{r}3.74 \\
5.24 \\
6.01 \\
7.89 \\
13.17\end{array}$ & $\begin{array}{r}3.70 \\
8.08 \\
8.91 \\
11.22 \\
11.88\end{array}$ & $\begin{array}{r}3.26 \\
4.96 \\
7.95 \\
10.22 \\
14.16\end{array}$ \\
\hline
\end{tabular}

cally adsorbed layer on the electrode surface in which the oasis environment can be established.

According to Table $\mathrm{I}$, all the $\mathrm{D}_{\mathrm{O}_{2}} \mathrm{C}_{\mathrm{O}_{2}}$ products of the modified electrolytes are considerably larger than that of $100 \% \mathrm{H}_{3} \mathrm{PO}_{4}$ at a certain temperature. From the trend in the improvements we see that the electrolyte modified by $1 \mathrm{w} / \mathrm{o}$ Si-550 is the best one, the electrolytes modified by 1 w/o $\mathrm{C}_{4}$-amine or $1 \mathrm{w} / \mathrm{o} \mathrm{C}_{4}$-salt also come close and the ones modified by $1 \mathrm{w} / \mathrm{o} \mathrm{C}_{6}$-salt or $1 \mathrm{w} / \mathrm{o} \mathrm{Si}-200$ are worse but still better than $100 \% \mathrm{H}_{3} \mathrm{PO}_{4}$. When a modified electrolyte contains different amounts of additives compared to those mentioned above, the temperature dependence of the $D_{\mathrm{O}_{2}} C_{\mathrm{O}_{2}}$ products also may be different; and for real fuel-cell application, in which high-surface-area gas-diffusion electrodes containing a dispersed $P t$ catalyst are used instead of the Pt working electrode, the situation may be different. Hence, what is observed in our electrochemical measurements on the modified electrolytes may not be entirely valid for real fuel-cell situations.

Conductivity of the modified electrolytes.-The results of the conductivity measurements are shown in Fig. 6 and 7. Figure 6 shows the modified electrolyte with 1.5 and $3 \mathrm{w} / \mathrm{o}$ of $\mathrm{C}_{4}$-salt as the additive to $\mathrm{H}_{3} \mathrm{PO}_{4}$, respectively. The conductivity at each composition increases with temperature. At a certain temperature, the conductivity decreases when the amount of the $\mathrm{C}_{4}$-salt increases because when an amount of $\mathrm{C}_{4}$-salt is added to the $\mathrm{H}_{3} \mathrm{PO}_{4}$, the hydrogen ion concentration of the resulting mixture decreases. The current is carried predominantly by hydrogen ion diffusion. Therefore the conductivity decreases with the $\mathrm{C}_{4}$-salt addition. The conductivity of the $100 \mathrm{w} / 0 \mathrm{H}_{3} \mathrm{PO}_{4}$ is included for comparison.

Figure 7 similarly shows the conductivity-temperature relationships of the modified electrolyte when $3.0 \mathrm{w} / \mathrm{o}$ of $\mathrm{C}_{4}$-amine was used as an additive to the $100 \% \mathrm{H}_{3} \mathrm{PO}_{4}$. The curves completely overlap which means that the conductivity is not at all affected by the $\left(\mathrm{C}_{4} \mathrm{~F}_{9}\right)_{3} \mathrm{~N}$ additions. This result was expected for such an oily compound which, under an unstirred condition, easily separated from the $\mathrm{H}_{3} \mathrm{PO}_{4}$ emulsion to form bigger drops. Therefore the measured conductivity of the mixtures were the conductivity of the $100 \mathrm{w} / \mathrm{o} \mathrm{H}_{3} \mathrm{PO}_{4}$ alone.

The conductivity of the other modified electrolytes was not measured. We expect that the conductivity of the $\left(\mathrm{C}_{6} \mathrm{~F}_{13} \mathrm{SO}_{3} \mathrm{~K}\right)$-modified electrolyte is similar to that of the $\mathrm{C}_{4}$-salt-modified electrolyte and that the silicone fluidmodified electrolytes behave similarly to those of the $\mathrm{C}_{4}$ amine-modified.

Wettability of the fuel-cell electrodes.-As mentioned earlier, the electrolytes containing longer fluorocarbon tail(s) have lower Tefion contact angles and tend to wet Teflon-bonded gas-diffusion electrodes. It is expected that by using perfluorinated acid salts as additives this problem is solved in part. A series of tests were performed by placing drops of electrolyte on the surface of a Teflon-bonded gas-diffusion electrode (Prototech) to examine briefly the contact angle between the electrolyte and the surface of the electrode at room temperature (the contact angle of an absolute sphere is defined as $180^{\circ}$ ).

A drop of $100 \% \mathrm{H}_{3} \mathrm{PO}_{4}$ electrolyte formed a spherical bead, which means that this electrolyte does not wet Teflon. When $\mathrm{C}_{6}$-salt was the electrolyte additive, the contact angle became much lower, decreasing with increasing concentration of $\mathrm{C}_{6}$-salt. This means that the $\mathrm{C}_{6}$-salt modified electrolyte can wet Teflon. The flooding of the electrodes in real working cells, however, might be avoided by regulating the gas pressure. The $\mathrm{C}_{4}$-salt electrolyte behaved much like the $\mathrm{C}_{6}$-salt electrolyte but slightly better because of the relatively shorter fluorocarbon tail. In the case of the $\mathrm{C}_{4}$-amine

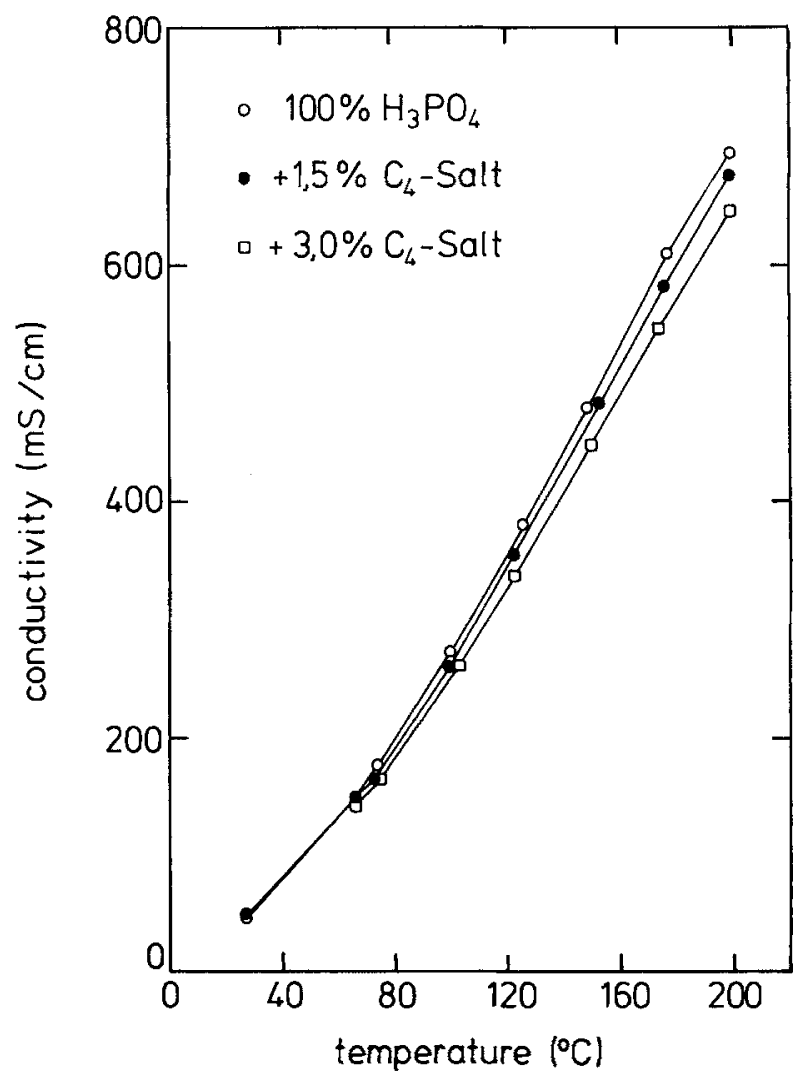

Fig. 6. Specific conductivity vs. temperature in electrolytes modified with $\mathrm{C}_{4}$-salt. 


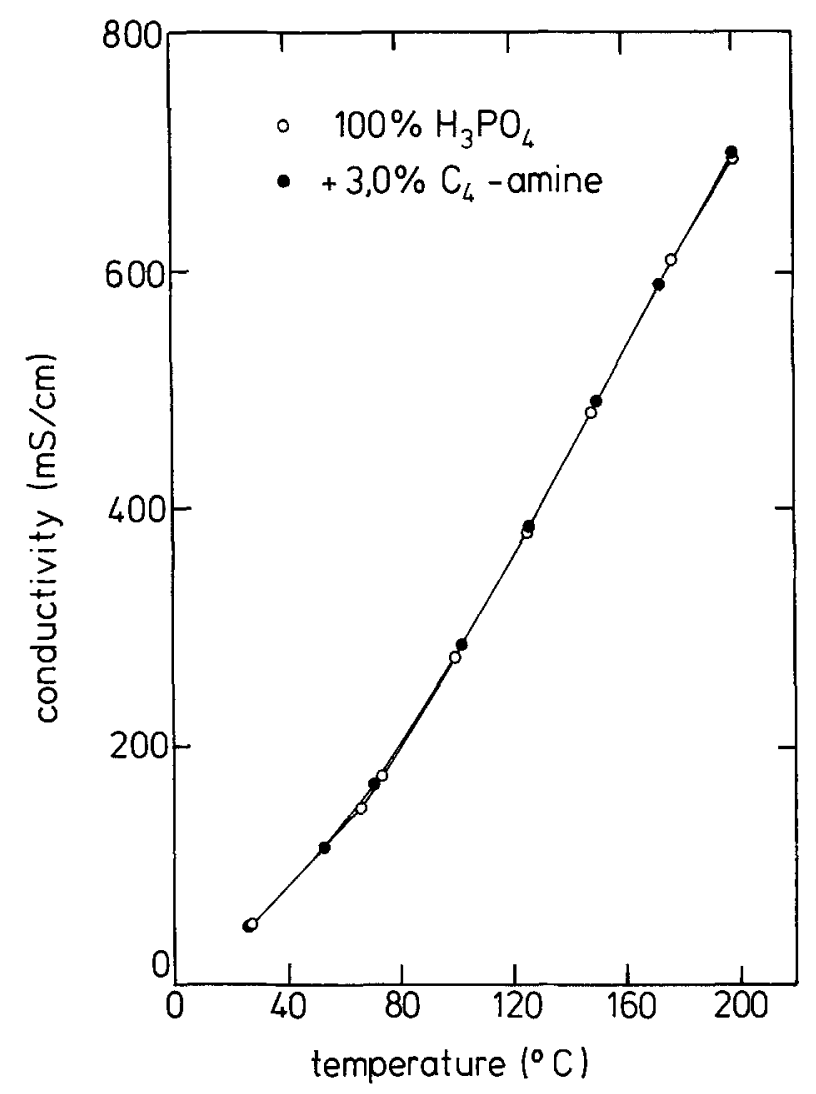

Fig. 7. Specific conduclivity vs. temperature in electrolytes modified with $\mathrm{C}_{4}$-amine.

modified electrolyte, all drops formed spherical beads, meaning that this electrolyte does not wet Teflon, and moreover, its contact angle with the Teflon-bonded electrode surface is higher than for $100 \% \mathrm{H}_{3} \mathrm{PO}_{4}$. This is a desirable property. The electrolytes modified with $\mathrm{Si}-500$ behaved like the $\mathrm{C}_{4}$-amine-modified electrolytes, as expected. The measured contact angles are reported in Table II.

Fuel-cell performance with the modified electrolytes.The fuel-cell experiments reported as follows were performed to test the electrolytes in the Giner cell housing. The electrodes were Pt-catalyzed carbon gas-diffusion electrodes prepared by the tape-casting method $\left(0.5 \mathrm{mg} / \mathrm{cm}^{2} \mathrm{Pt}\right.$ loading on both anode and cathode). All the experiments were carried out at $190^{\circ} \mathrm{C}$, using pure hydrogen (Dansk Ilt $\&$ Brintfabrik A/S) as the fuel and pure oxygen (Dansk Ilt $\&$ Brintfabrik A/S) as the oxidant, respectively.

In the beginning of the each test, cell performance improved after each polarization cycle until, after 3 to 4 cycles, a steady-state behavior was observed. This probably was due to an increase in wetting of active sites with time. Time also was an important factor. Approximately one

Table II. The confact angles between the Prototech gas-diffusion electrode and the electrolytes.

\begin{tabular}{|c|c|}
\hline Electrolyte & Contact angle degree \\
\hline $100 \mathrm{w} / \mathrm{o} \mathrm{H}_{3} \mathrm{PO}_{4}$ & 94 \\
\hline $\begin{array}{l}0.5 \mathrm{w} / \mathrm{o} \mathrm{C}_{6} \text {-salt } \\
1.0 \mathrm{w} / \mathrm{o} \mathrm{C}_{6} \text {-salt } \\
1.5 \mathrm{w} / \mathrm{o} \mathrm{C}_{6} \text {-salt }\end{array}$ & $\begin{array}{l}42 \\
36 \\
31\end{array}$ \\
\hline $\begin{array}{l}0.5 \mathrm{w} / 0 \mathrm{C}_{4} \text {-salt } \\
1.0 \mathrm{w} / \mathrm{o} \mathrm{C} \mathrm{C}_{4} \text {-salt } \\
1.5 \mathrm{w} / \mathrm{o} \mathrm{C} \mathrm{C}_{4} \text {-salt } \\
3.0 \mathrm{w} / \mathrm{o} \mathrm{C} \mathrm{C}_{4} \text {-salt }\end{array}$ & $\begin{array}{l}59 \\
45 \\
28 \\
28\end{array}$ \\
\hline $\begin{array}{l}0.5 \mathrm{w} / 0 \mathrm{C}_{4} \text {-amine } \\
1.0 \mathrm{w} / 0 \mathrm{C}_{4} \text {-amine } \\
1.5 \mathrm{w} / 0 \mathrm{C}_{4} \text {-amine } \\
3.0 \mathrm{w} / \mathrm{O} \mathrm{C}_{4} \text {-amine }\end{array}$ & $\begin{array}{l}125 \\
124 \\
125 \\
123\end{array}$ \\
\hline $1.0 \mathrm{w} / \mathrm{o}$ silicone oil DC-550 & 112 \\
\hline
\end{tabular}

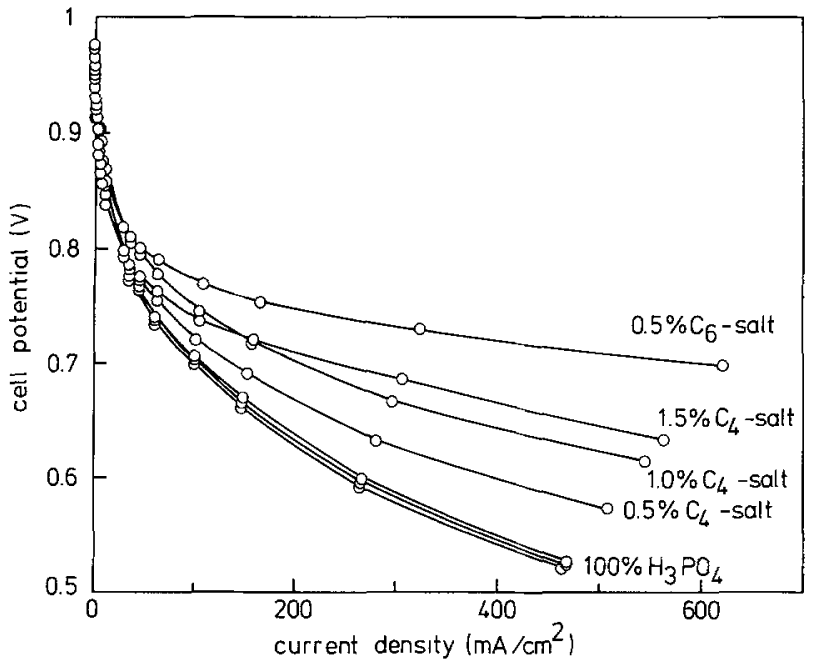

Fig. 8. Polarization curves for electrolyte modified by addition of $\mathrm{C}_{6}$-salt and $\mathrm{C}_{4}$-salt (fuel, $\mathrm{H}_{2}$; oxidant, $\mathrm{O}_{2}$; electrolyte, $100 \% \mathrm{H}_{3} \mathrm{PO}_{4}$; and temperature, $190^{\circ} \mathrm{C}$ ).

week elapsed before a steady and reliable result was obtained. Polarization curves reported in Fig. 8-11 and discussed below were recorded after the fifth cycle. The current density for the cell was calculated from the measured voltage and the measured resistance of the external load. This procedure leads, due to an unmeasured and varying contact resistance, to a small error in the current density (e.g., $25 \mathrm{mV}$ at $500 \mathrm{~mA} / \mathrm{cm}^{2}$ ).

Electrode reproducibility tests.-To compare the various types of electrolytes, we must demonstrate that the electrode and cell assembly can be made in a reproducible way. The lower three polarization curves in each of Fig. 8 to 10 , and the three upper ones of Fig. 11 show the reproducibility of the electrodes. In all cases, $100 \% \mathrm{H}_{3} \mathrm{PO}_{4}$ was used as the electrolyte. The electrodes can be manufactured reproducibly by us.

From Fig. 8 we see that there is a pronounced effect for the $0.5 \mathrm{w} / 0 \mathrm{C}_{6}$-salt-modified electrolyte. The cell tests also show that electrolytes modified by $\mathrm{C}_{4}$-salt can improve cell performance compared to the $100 \% \mathrm{H}_{3} \mathrm{PO}_{4}$ electrolyte, and increasing the amount of $\mathrm{C}_{4}$-salt also increase cell performance.

Figure 9 shows that electrolytes modified by $\mathrm{C}_{4}$-amine can improve the cell performance compared to the $100 \%$ $\mathrm{H}_{3} \mathrm{PO}_{4}$ electrolyte, and increasing the amount of $\mathrm{C}_{4}$-amine also increases cell performance.

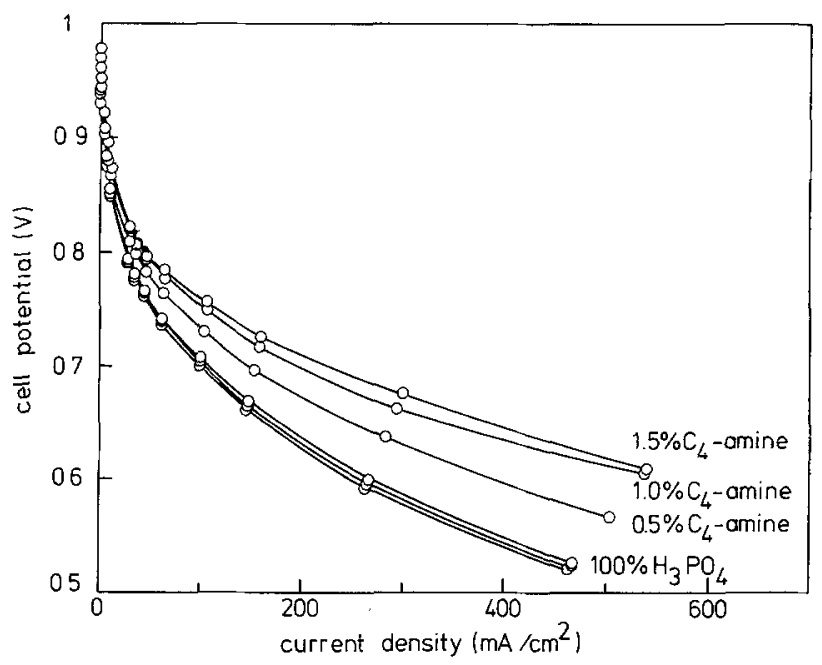

Fig. 9. Polarization curves for electrolyte modified by addition of $\mathrm{C}_{4}$-amine (fuel $\mathrm{H}_{2}$; oxidant, $\mathrm{O}_{2}$; electrolyte, $100 \% \mathrm{H}_{2} \mathrm{PO}_{4}$, and temperature, $190^{\circ} \mathrm{C}$ ). 


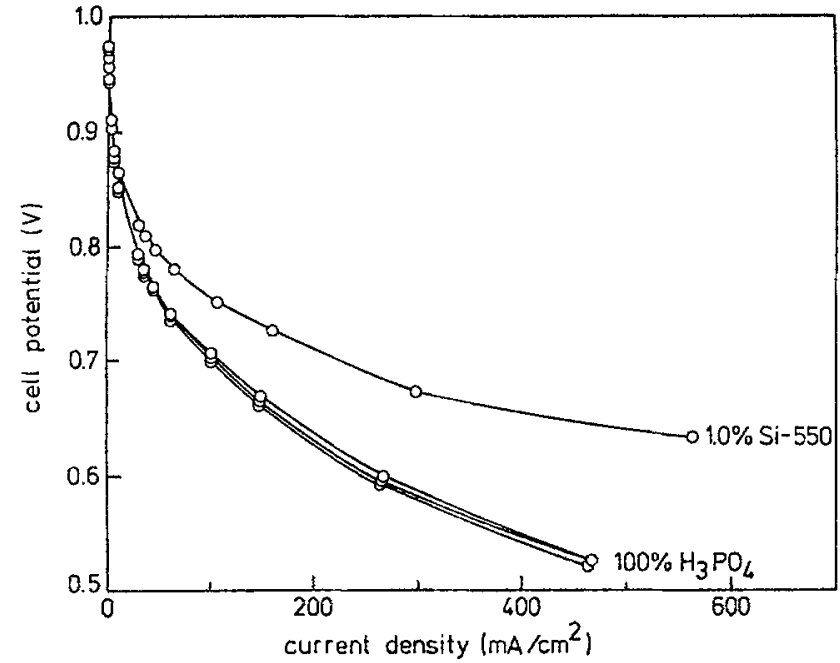

Fig. 10. Polarization curves for electrolyte modified by addition of Si-55O (fuel, $\mathrm{H}_{2}$; oxidant, $\mathrm{O}_{2}$; electrolyte, $100 \% \mathrm{H}_{3} \mathrm{PO}_{4}$; temperature, $190^{\circ} \mathrm{Cl}$.

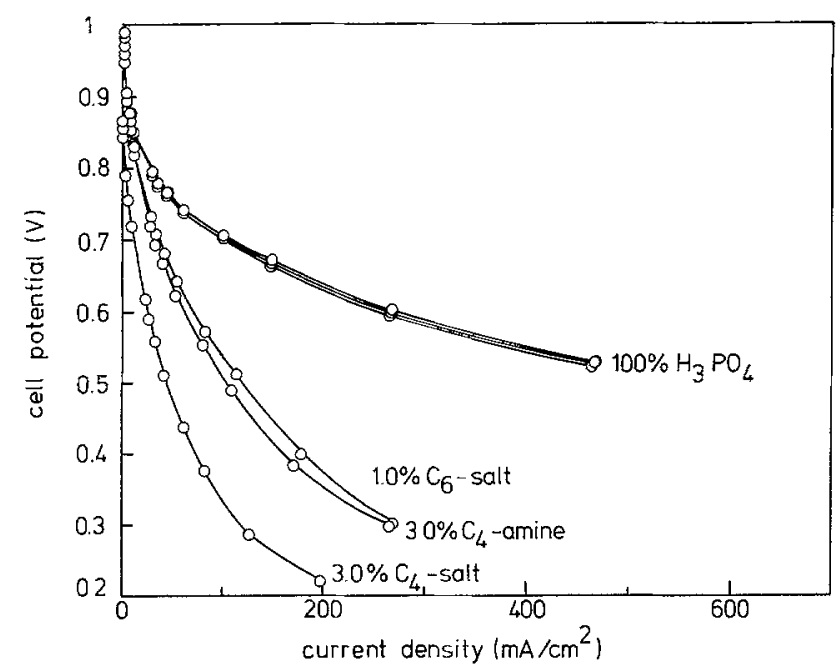

Fig. 11 Polarization curves when excess amount of additives were used to the modified electrolytes (fuel, $\mathrm{H}_{2}$; oxidant, $\mathrm{O}_{2}$; electrolyte, $100 \% \mathrm{H}_{3} \mathrm{PO}_{4}$; temperature, $190^{\circ} \mathrm{C}$.

Figure 10 shows that improved cell performance can be obtained with an electrolyte modified with Si-550 addition.

Difference in behavior and limitation in the amount of additive.-The differences between the polarization curves for the modified electrolytes and the unmodified electrolyte increase with increasing current densities. This suggests that the difference in diffusion coefficients (between modified and unmodified electrolytes) is a major factor since diffusion is more important at higher current densities.

From Fig. 8-10, we see that the electrolyte modified with $0.5 \mathrm{w} / \mathrm{o} \mathrm{C}_{6}$-salt works best, $1.5 \mathrm{w} / \mathrm{o} \mathrm{C}_{4}$-salt second best, 1.5 $\mathrm{w} / \mathrm{o} \mathrm{C}_{4}$-amine third best, and $1 \mathrm{w} / \mathrm{o} \mathrm{Si}-550$ fourth best. This order does not agree exactly with the result from the electrochemical measurements of the modified electrolytes probably due to the different environments between the two electrode systems.

Figure 11 shows the polarization curves when $1.0 \mathrm{w} / \mathrm{o}$ of $\mathrm{C}_{6}$-salt, $3.0 \mathrm{w} / \mathrm{o}$ of $\mathrm{C}_{4}$-salt, and $3.0 \mathrm{w} / \mathrm{o}$ of $\mathrm{C}_{4}$-amine were used as the additives, respectively. They all show decreased performance in comparison to the 100 w/o $\mathrm{H}_{3} \mathrm{PO}_{4}$ electrolyte. $\mathrm{C}_{6}$-salt and $\mathrm{C}_{4}$-salt have long fluorocarbon chains and are able to wet Teflon to some extent. From Figure 11 it is apparent that the amount of $\mathrm{C}_{6}$-salt and $\mathrm{C}_{4}$-salt used are in excess of the limitations for flooding the Teflonbonded electrodes. In the case of $\mathrm{C}_{4}$-amine, the problem could be that the excess amount of the $\mathrm{C}_{4}$-amine increases the thickness of the so-called self-assembling layer blocking most of the active sites. Excess amounts of silicone oil DC- 550 have not been tried, but a behavior such as that of $\mathrm{C}_{4}$-amine is expected.

More studies, particularly on the performance of the cathode in the fuel cell with the modified electrolytes at elevated temperatures $\left(\mathrm{ca} .200^{\circ} \mathrm{C}\right)$ over extended periods, are necessary to clarify the technical importance of the additives. However we know that an addition of $0.5 \mathrm{w} / \mathrm{o} \mathrm{C}_{6^{-}}$ salt gives a stable improvement in cell performance over more than three months.

\section{Acknowledgments}

The authors are grateful to the Danish Ministry of Energy, Augustinus Fonden, COWIfonden, Tuborgfondet, and A/S Fisker and Nielsens Fond for their financial support.

Manuscript submitted April 7, 1992; revised manuscript received Dec. 4, 1992.

\section{REFERENCES}

1. P. Andricacos and P. Ross, J. Electroanal. Chem. Interfacial Electrochem., 154, 205 (1983)

2. E. Yeager, S. Clouser, M. A. Enayetullah, and G. Ervasio, EPRI Report AP5779LD (1988)

3. A. A. Adams and H. Barger, This Journal, 121, 987 (1974).

4. A. A. Adams, R. Foley, and H. Barger, ibid., 124, 1228 (1977).

5. A. J. Appleby and B. S. Baker, ibid., 125, 404 (1978)

6. P. N. Ross, ibid., 130, 882 (1983).

7. K. Striebel, P. Andricacos, E. Caims, P. Ross, and F. McLarnon, ibid, 132, 2381 (1984).

8. W. E. O'Grady, Gas Research Institute Final Report (1982-1985).

9. M. Razaq, A. Razaq, and E. Yeager, Gas Research Institute Annual Report (1986 1987).

10. M. Razaq, A. Razaq, and E. Yeager, Gas Research Institute Final Report (1989).

11. X. Gang, H. A. Hjuler, C. Olsen, R. W. Berg, and N. J. Bjerrum, Danish Pat. Application 1272/91 (1991); Pat. pending in other countries.

12. L. C. Clark and F. Gillan, Science, 152, 1755 (1966).

13. K. K. Tremper, A. E. Friedman, E. M. Levine, R. Lapin, and D. Camarillo, New Eng.J. Med., 307, 277 (1982).

14. H. A. Sloviter, M. Petkovic, S. Ogoshi, and H. Yamada, J. Appl. Physiol., 27, 666 (1969).

15. W. E. O'Grady and J. Zagal, Abstract 301, p. 486, The Electrochemical Society Extended Abstracts, Vol. 82-2, Detroit, MI, Oct. 17-21, 1982.

16. K-L. Hsueh, H. H. Chang, D-T. Chin, and S. Srinivasan, Electrochim. Acta, 30, 1137 (1985).

17. M. A. Enayetullah, Ph.D. Thesis, Case Western Reserve University, Cleveland, OH (1986).

18. M. A. Enayetullah, E. J. M. O'Sullivan, and E. B. Yeager, J. Appl. Electrochem., 18, 763 (1988).

19. J. Giner, This Journal, 111, 376 (1964).

20. G. Jones and B. C. Bradshaw, J. Am. Chem. Soc., 55 $1780(1933)$

21. H. A. Hjuler, R. W. Berg, K. Zachariassen, and N. J. Bjerrum, J. Chem. Eng. Data, 30, 203 (1985).

22. P. Zelenay, B. R. Scharifker, J. O'M. Bockris, and D. Gervasio, This Journal, 133, 2262 (1986)

23. C. P. Winlove, K. H. Parker, and R. K. C. Oxenham, J. Electroanal. Chem. Interfacial Electrochem., 170, 293 (1984).

24. P. Zelenay, M. A. Habib, and J. O'M. Bockris, This Journal, 131, 2464 (1984).

25. M. Razaq, A. Razaq, E. Yeager, D. D. DesMarteau, and S. Sing, ibid., 136, 385 (1989). 